\title{
Managing the Chao Phraya River and Delta in Bangkok, Thailand: Flood Control, Navigation and Land Subsidence Mitigation
}

\author{
Kenneth R. Olson' ${ }^{1}$, William Kreznor ${ }^{2}$ \\ ${ }^{1}$ Department of Natural Resources and Environmental Sciences College of Agricultural, Consumer, and Environmental Sciences, \\ University of Illinois, Urbana, USA \\ ${ }^{2}$ W.R. Kreznor \& Associates, Inc., Woodstock, Illinois, USA \\ Email: krolson@illinois.edu
}

How to cite this paper: Olson, K.R. and Kreznor, W. (2021) Managing the Chao Phraya River and Delta in Bangkok, Thailand: Flood Control, Navigation and Land Subsidence Mitigation. Open Journal of Soil Science, 11, 197-215.

https://doi.org/10.4236/ojss.2021.114011

Received: March 4, 2021

Accepted: April 9, 2021

Published: April 12, 2021

Copyright $\odot 2021$ by author(s) and Scientific Research Publishing Inc. This work is licensed under the Creative Commons Attribution International License (CC BY 4.0).

http://creativecommons.org/licenses/by/4.0/

\section{(c) (i) Open Access}

\begin{abstract}
Land subsidence as a result of the groundwater withdrawals in the Chao Phraya Delta in Thailand will be studied along with any successful remediation efforts. Most of the deltas of South East Asia are sinking for a variety of reasons. Thailand has national concerns related to land subsidence as a result of sea level rise, climate change, flooding, storm surges, skyscrapers, compaction, and groundwater extraction for rice paddies, shrimp ponds and the drinking water and household needs of approximately 15 million people living on the Chao Phraya Delta. The Chao Phraya River shoreline line is eroding and significant land areas and wetlands are being lost and becoming open water. Urban areas are periodically flooded and require earthen levees or floodwalls. The objective is to assess and mitigate land subsidence as a result of groundwater withdrawals for rice paddies, aquaculture, shrimp ponds, industry, drinking water and household needs of 15 million people living on Chao Phraya Delta in Bangkok. The impact of groundwater extraction and reduced sedimentation on land subsidence in the Chao Phraya Delta will be assessed and mitigation methods recommended. Lessons learned and successful remediation efforts in one Southeast Asia delta may or may not be applicable to other South East Asia deltas. There need to be mitigation methods identified to add sediment to existing Chao Phraya Delta wetlands. River water also needs to be injected deep into the underlying alluvial sediments in the delta. Navigation in the canal systems could be adversely affected by proposed massive Chao Phraya River water injections into the Chao Phraya Delta alluvial sediments underlying Bangkok.
\end{abstract}

\section{Keywords}

Ayutthaya, Port of Bangkok, Shore Erosion, Gulf of Thailand, Rice, Shrimp 


\section{Introduction}

The capital of Thailand, Bangkok is the home of 15 million people and is situated on the Chao Phraya River and Delta. The city is located $28 \mathrm{~km}$ north of the Gulf of Thailand. It is known as "The Venice of the East" with dozens of large canals (Klongs) which drain into the Chao Phraya River [1]. The water table is at or near the surface throughout the Bangkok area (Chao Phraya Delta). During the monsoon season many areas in Bangkok flood. The city has been subsiding at the rate as high as 10 to $12 \mathrm{~cm}$ per year and some areas have already subsided $150 \mathrm{~cm}$ or more. Parts of the city are now below sea level and require floodwalls (Figure 1) or to be on stilts (Figure 2) especially in the south-eastern metropolitan area where the floodwaters reside there for a much longer time period and drainage has become less efficient as a result of reduced gradients in storm drains and canals. Bangkok is on a nearly level marine-deltaic plain only 0.5 to $1.5 \mathrm{~m}$ above mean sea level. The past 50 years the groundwater pumping in Bangkok metropolitan had resulted in a reduction in pore pressure, compression of surficial deposits and silt, dramatic lowering of piezometric levels, and total ground subsidence of more than $0.5 \mathrm{~m}$. Artificial recharge is needed to restore piezometric heads of the multi-aquafer system.

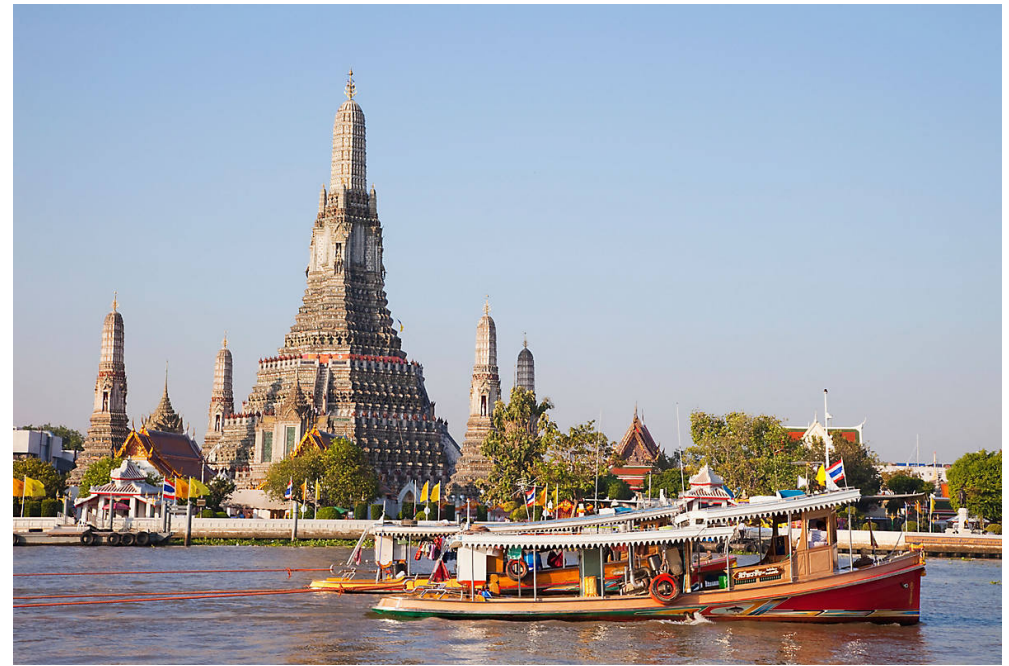

Figure 1. Floodwall protecting the Bangkok temples. In the foreground are tourist tour boats. Photograph taken by Pam Olson.

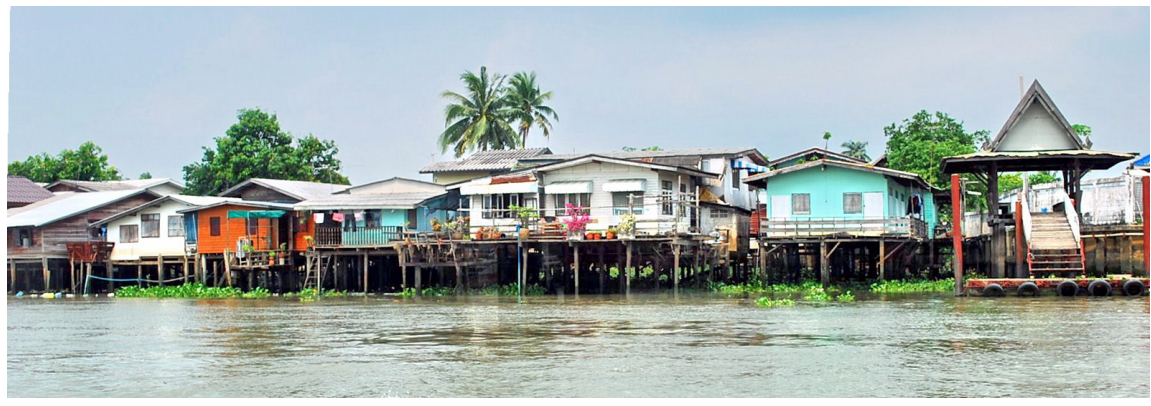

Figure 2. Homes on stills along the Chao Phraya River. Photograph taken by Pam Olson. 
The objective is to assess and mitigate land subsidence as a result of groundwater withdrawal for rice paddies, aquaculture, shrimp ponds, industry, and the drinking water and household needs of 15 million people living in Bangkok on Chao Phraya Delta.

\section{Location}

\subsection{Geomorphology and Geology}

About 8 million years ago the Mekong River flowed south and to the west of Khorat Plateau, confluence with local ancient rivers that became the current Chao Phraya River which runs through Bangkok. During the late Cretaceous and early Tertiary uplifting cause block or plate faulting in northern Thailand resulting in flat basins and steep mountain ranges. Apparently the subsidence in the Tonle Sap basin of Cambodia [2], perhaps within the last 12,000 years, drew the Mekong River eastward and away from its former Chao Phraya River connection to the Tonle Sap basin [3]. During Tertiary time period, fault block tectonics created the north-south structural depression where Central Plain and Gulf of Thailand are located. West of this huge depression is north-south trending Paleozoic fold belts. The eastern boundary of depression is rimmed by Khorat Plateau. The Khrok Phra Arch at Naknon Sawan borders to the north of the basin. The depression extends through the Gulf of Thailand to South China Sea. The lower Central Plain is underlain by basement arches, pluton, faults and flexture zones [4]. Wells drilled to bedrock revealed the alluvial and marine sediment thickness to be between 350 and $1800 \mathrm{~m}$.

\subsection{Subsoils}

The first attempt to delineate the subsurface strata in Bangkok [5] was for construction and design activities. Expansion of Bangkok in 1970s brought additional soil investigations which created a better understanding of surface conditions. The typical surface profiles are restricted to $30 \mathrm{~m}$. Piyasen [6] created two generalized profiles where the soft Bangkok clay has an average thickness of 14 $\mathrm{m}$ which is almost half of the typical $30 \mathrm{~m}$ profile below central Bangkok.

\subsection{Early Settlement and Channel Alignment Modifications}

In 1538 Thailand river modification and engineering was directed by the King Chairachathirat. A $3 \mathrm{~km}$ long canal was dug. It shortened the shipping route from Ayutthaya to the Gulf of Siam (Thailand) by $13-14 \mathrm{~km}$. Today the channel is identified as Khlong Bangkok Noi. In 1542, a $2 \mathrm{~km}$ canal, is now known as Khlong Bangkok Yai, shorten by $14 \mathrm{~km}$ the river route. In 1608 a $7 \mathrm{~km}$ long canal called Khlong Bay Phrao was finished. It reduced the Chao Phraya River trip by $18 \mathrm{~km}$. In 1636 the Khong lat Mueang Nonthaburi canal was completed. In 1977, the $2 \mathrm{~km}$ Kret Noi was completed to shorten the river by $7 \mathrm{~km}$.

\subsection{Chao Phraya Delta}

With the weight of people and skyscrapers (Figure 3 and Figure 4) contributing 


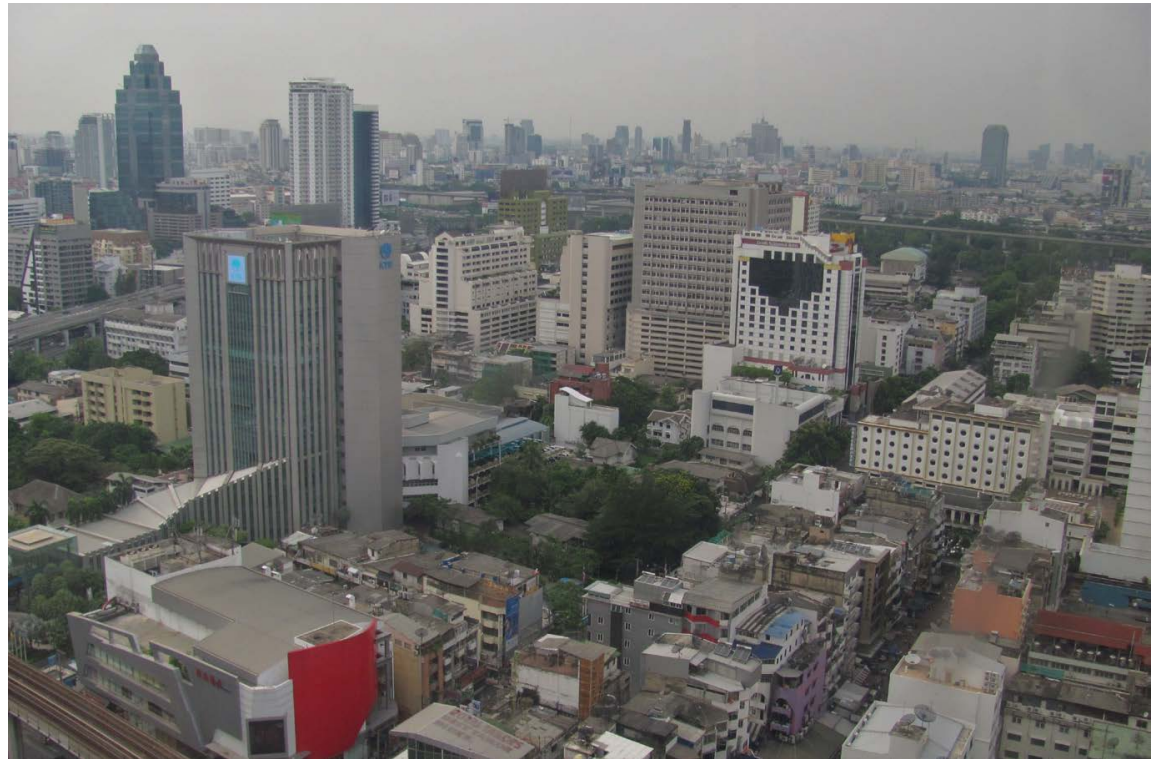

Figure 3. A view with many skyscrapers of Bangkok.

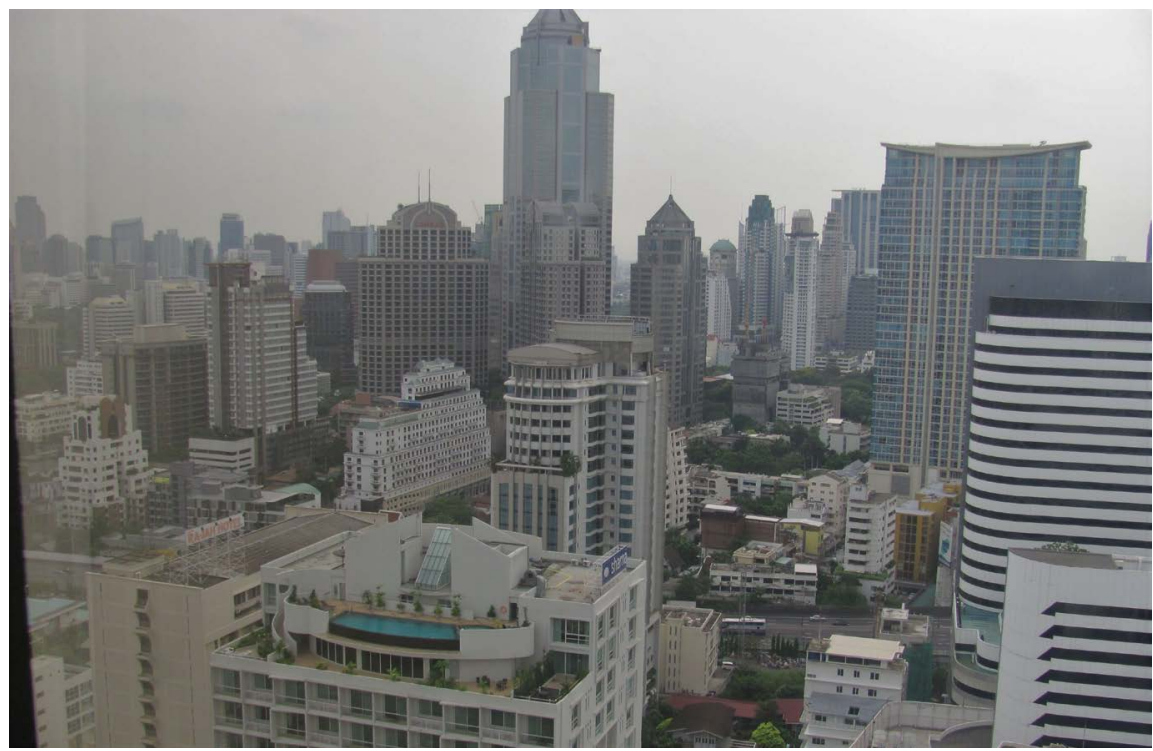

Figure 4. The heavy skyscrapers of Bangkok.

to the cities slow descent into the water, Bangkok has become a victim of its own successful urban development. Bangkok was built on the Chao Phraya Delta a once marshy land about $1.5 \mathrm{~m}$ above the sea level. The tarmac at the Don Muang airport was flooded in 2011. As temperatures increased, abnormal weather patterns with more erratic rainfall, more cyclones and increased floods (Figure 5) and droughts are predicted over time adding pressure on the Thailand government to address the potential climate change with greater frequency of extremes. Bangkok is projected to be one of the world's hardest hit urban areas along with Jakarta, Ho Chi Minh City and Manila. Bangkok is sinking one to two $\mathrm{cm}$ a year with the risk of massive flooding in the next few years. The Gulf of Thailand is rising by $4 \mathrm{~mm} / \mathrm{yr}$ which is above the global sea rise average. 


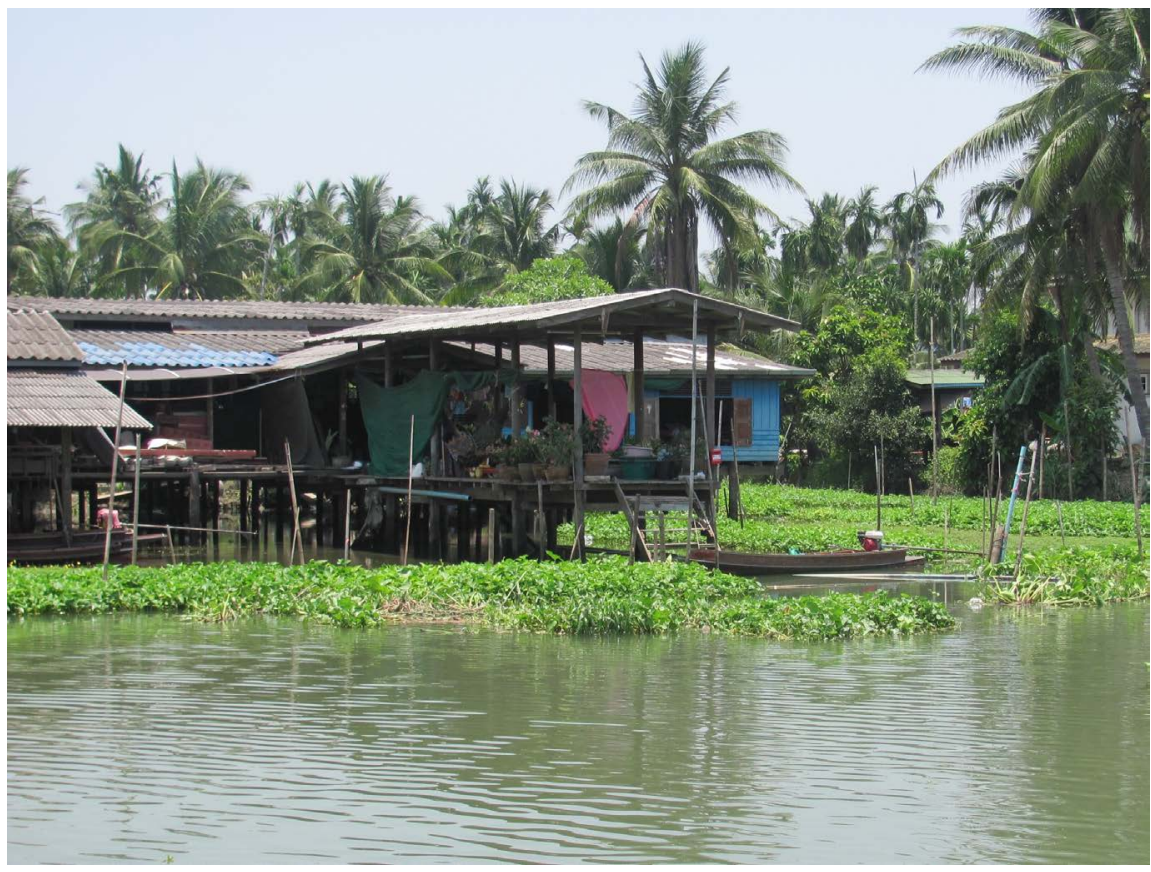

Figure 5. House on stilts during a flooding event along the Chao Phraya River in Bangkok. Photograph taken by Pam Olson.

In 2011, the monsoon season brought the worst flooding in decades, a fifth of the city was underwater (Figure 5). The business district was spared thanks to hastily constructed levees and dikes. The rest of the Thailand was not so lucky, approximately 500 people lost their life by the end of the 2011 monsoon season. Sections of Bangkok are already partially below sea level.

\subsection{Increased Flooding Disasters in Bangkok}

In 1985 with floundering infrastructure, worsening floods, and rapidly rising costs of pumping storm water into the Gulf of Thailand, the government raised taxes. Groundwater use decline resulted in the subsidence rate being reduced by $1-2 \mathrm{~cm}$ per year [7]. To make up for groundwater declines, Bangkok shifted to using treated surface water from Chao Phraya River.

The Chao Phraya River in Thailand confluences of the Ping, Wang, Yom and Nan rivers (Figure 6) which are located in the mountains of Northern Thailand. The Chao Phraya River is the main stem river of Thailand. It flows $365 \mathrm{~km}$ into the Gulf of Thailand. The river falls less than $24 \mathrm{~m}$ in its voyage to the sea. The Chao Phraya watershed has $160,080 \mathrm{~km}^{2}$ with several major irrigation projects. The Chao Phraya River basin is a filled in arm of the Gulf of Thailand (Figure 6). The delta plain surrounding Bangkok is no more than $2 \mathrm{~m}$ above sea level. Annual flooding brings rich alluvial sediment to the rice fields. In the delta, the Chao Phraya, the Mae Kong (to the west) and the Bang Pakong (to the east) are linked by a network of canals (Figure 7).

Thailand's capitals, both Ayutthaya (past) and Bangkok (present) were located on its banks as have many other cities been situated on its tributaries and distributaries. 


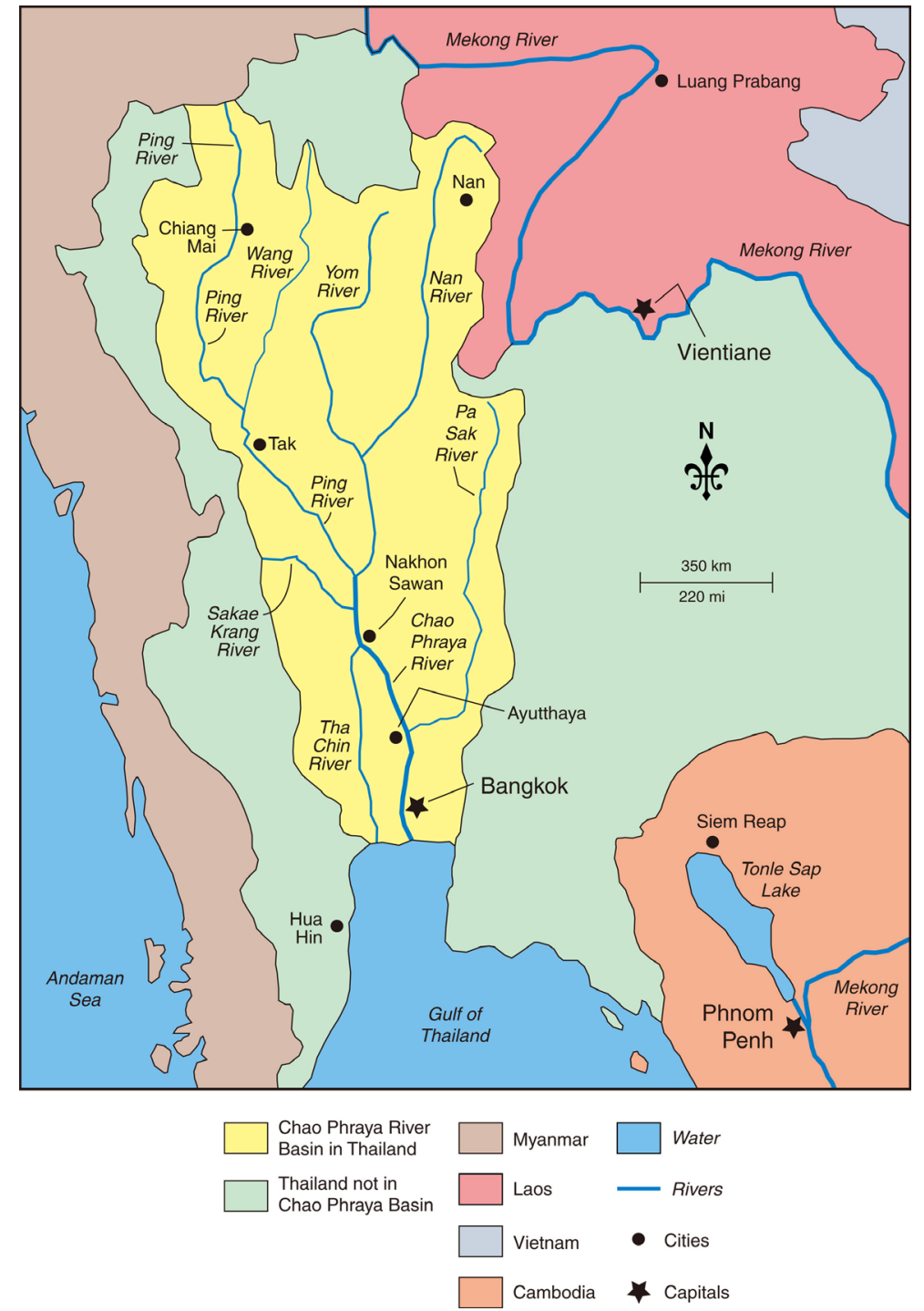

Figure 6. Map of rivers in Thailand. Map created by Mic Greenberg.

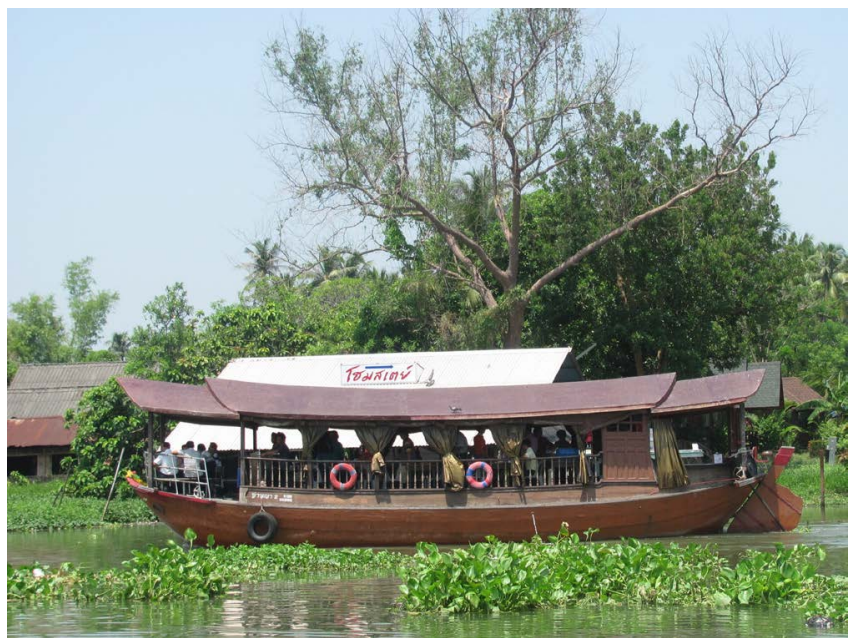

Figure 7. Transportation of tourists by boat on the Chao Phraya River. Photograph taken by Pam Olson. 


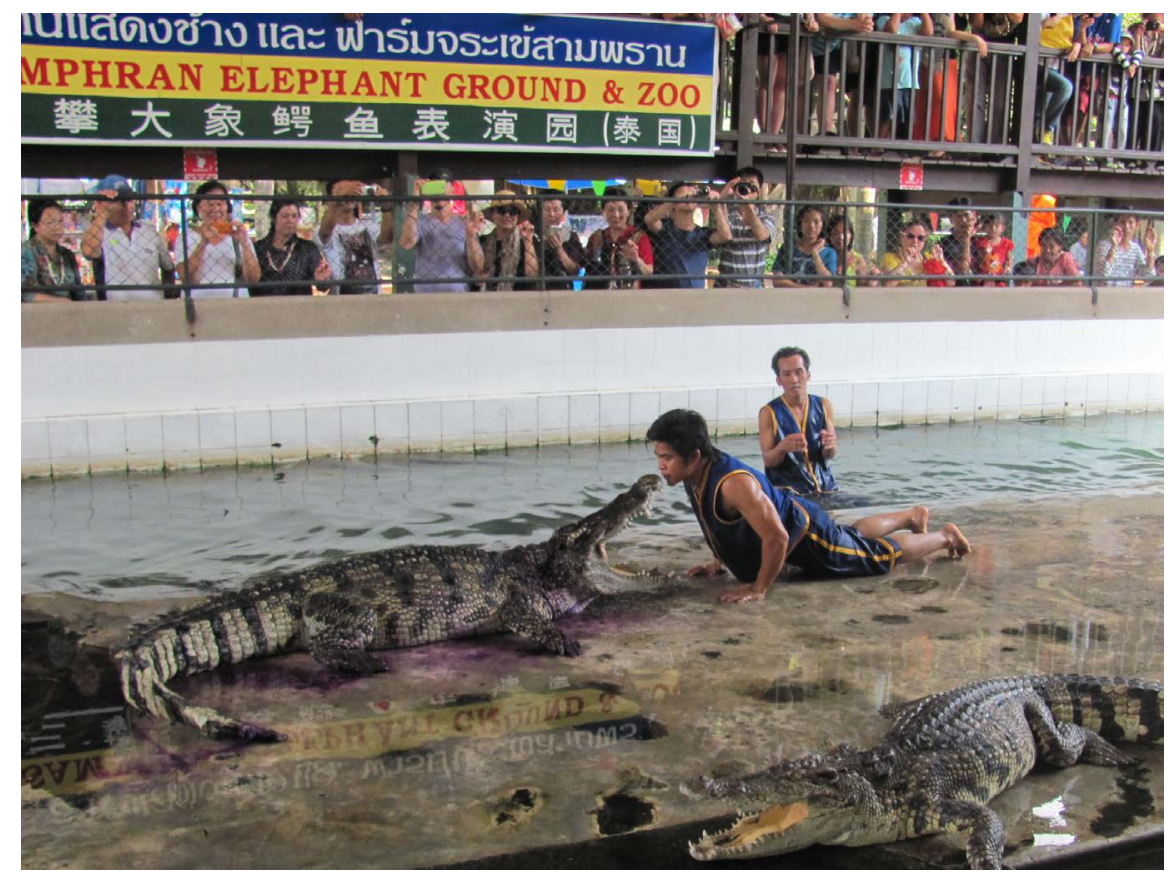

Figure 8. Alligators and handlers at an Elephant Zoo during a show. Photograph taken by Pam Olson.

Chao Phraya River is a tidal river between Ayutthaya and the Gulf of Thailand. The river (Figure 7) serves as the export pathway for teak and rice. The Thai people have made use of the Chao Phraya and its canal system for fishing, recreation (Figures 8-16), drainage and as the source of water. The Chai Phraya River flows past Chai Nat the home of a government dam and a large irrigation system. The Tha Chin River is the major distributary of the Chao Phraya River (Figure 6). These rivers are interconnected and serve both for irrigation and for transportation.

Bangkok occupies an area of about $1540 \mathrm{~km}^{2}$ near the southern margin of a low-lying flat, marine-plain termed the Central Lowlands. The upper central Plain begins (Figure 6) where the Ping, Wang, Yom and Bam rivers join. These four rivers combine to form the Chao Phraya River near Nokhon Sawan $240 \mathrm{~km}$ north of Bangkok. The modern Chao Phraya River has developed a $10 \mathrm{~km}$ wide meander belt in the Lower Central Plain. Its levees are poorly connected and low (Figure 17 and Figure 18) and cannot prevent flooding large bottomland area north of Bangkok (Figure 19) especially during monsoon flows.

The Chao Phraya is the river of kings and the city of Bangkok was designed to be seen by the people from the water. The Thai are river people (Figure 20) and the more congested the road traffic becomes, the more the people of Bangkok dream of returning to their river. Bangkok, a city with more than $15,000,000$ people can be seen from the river. Older inhabitants in shadow of new concrete and glass high rises (Figures 21-23), are still living waterborne lives in stilt-houses (Figure 5), and on barges, dependent on the brown river for their washing, fishing and transportation (Figure 20). People living on barges, near Krung 


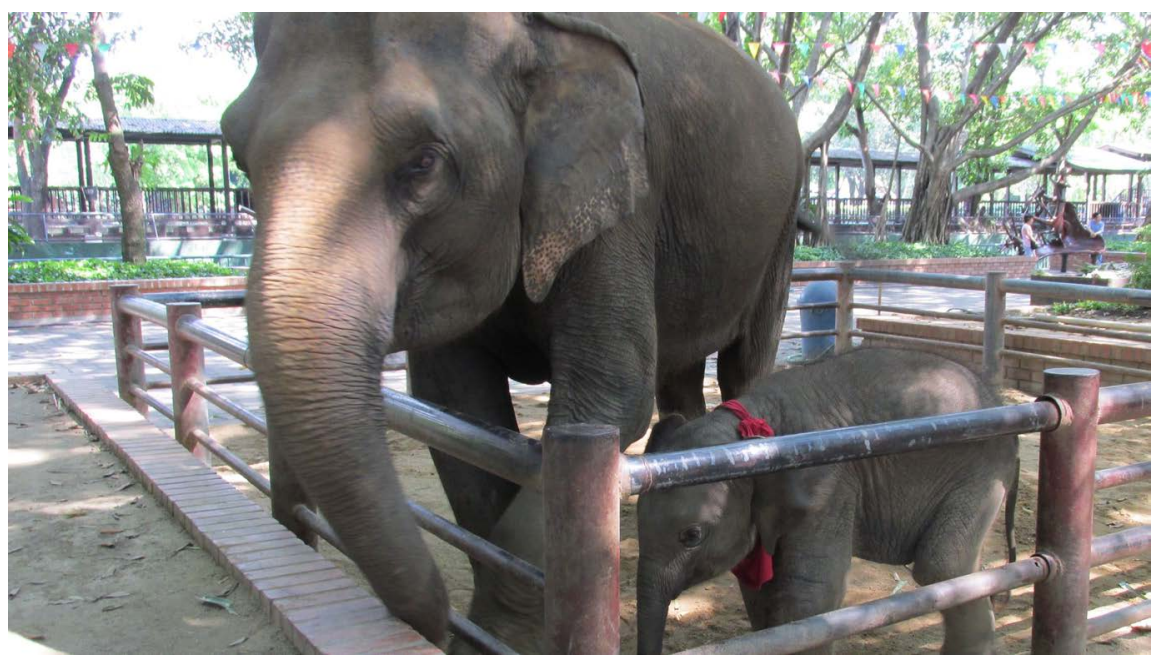

Figure 9. Elephants at the Elephant Zoo. Photograph taken by Pam Olson.

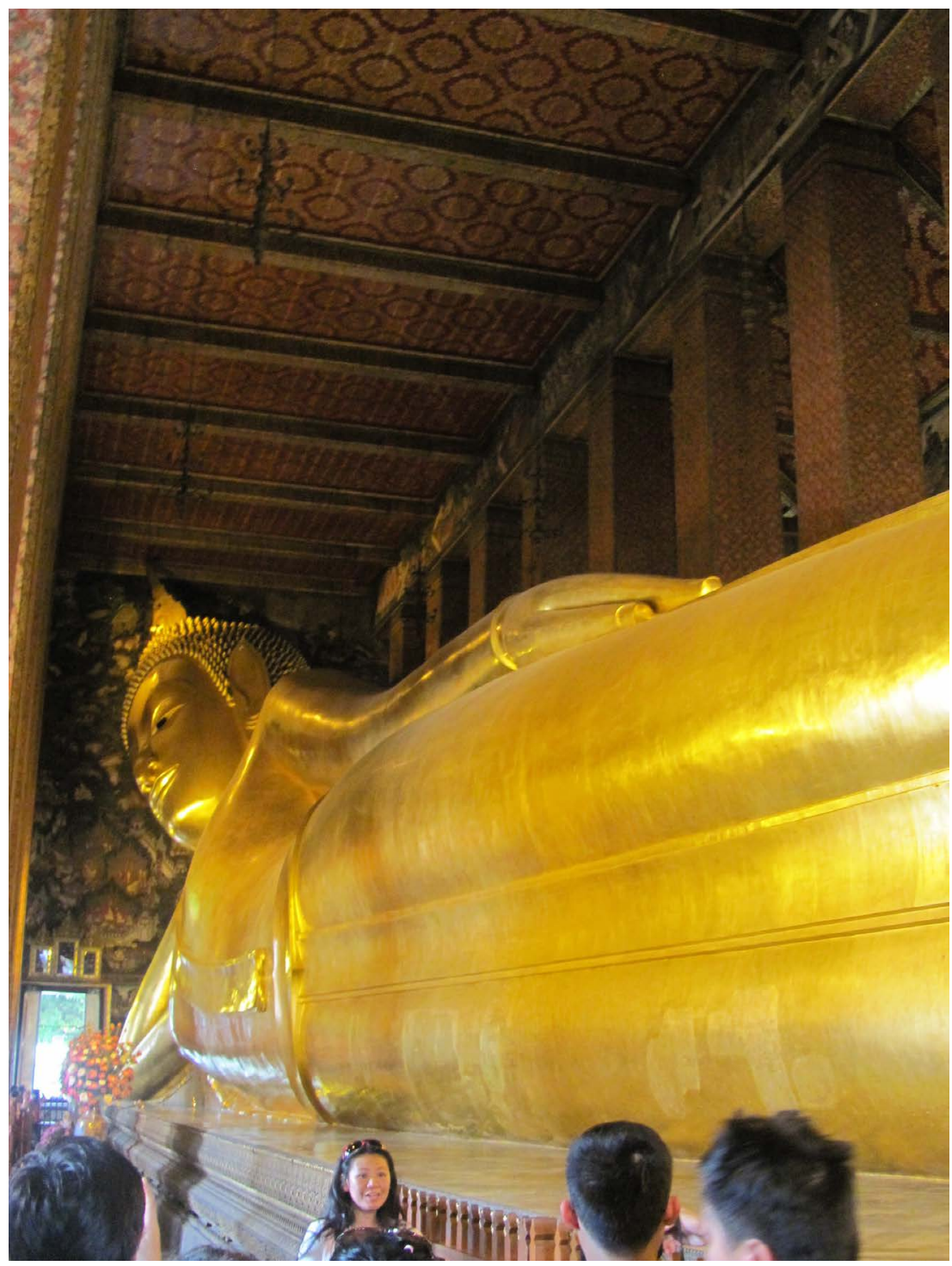

Figure 10. Budda lying down in a Bangkok temple. Photograph taken by Pam Olson. 


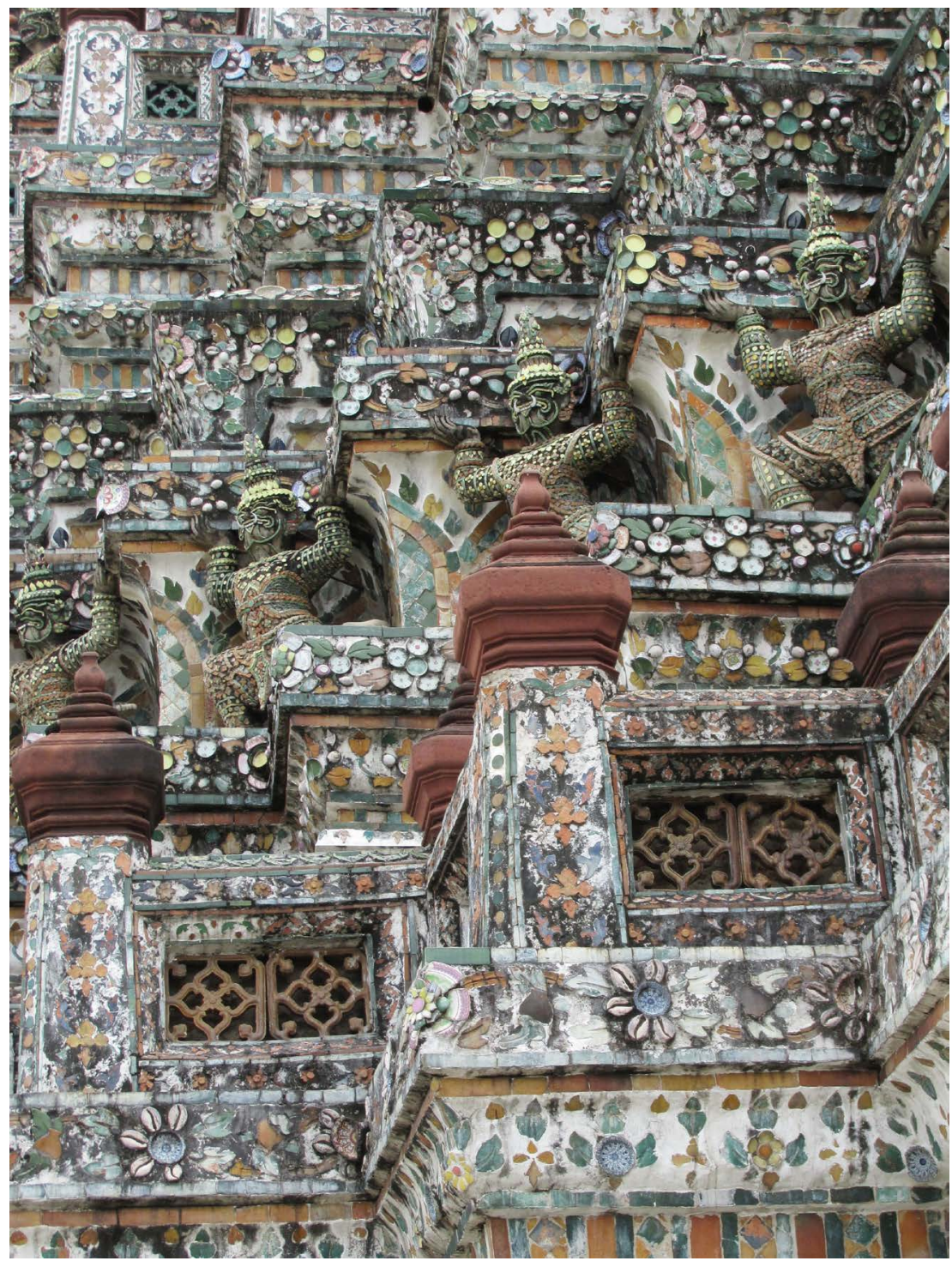

Figure 11. Temple decorations on a Bangkok temple. Photograph taken by Pam Olson.

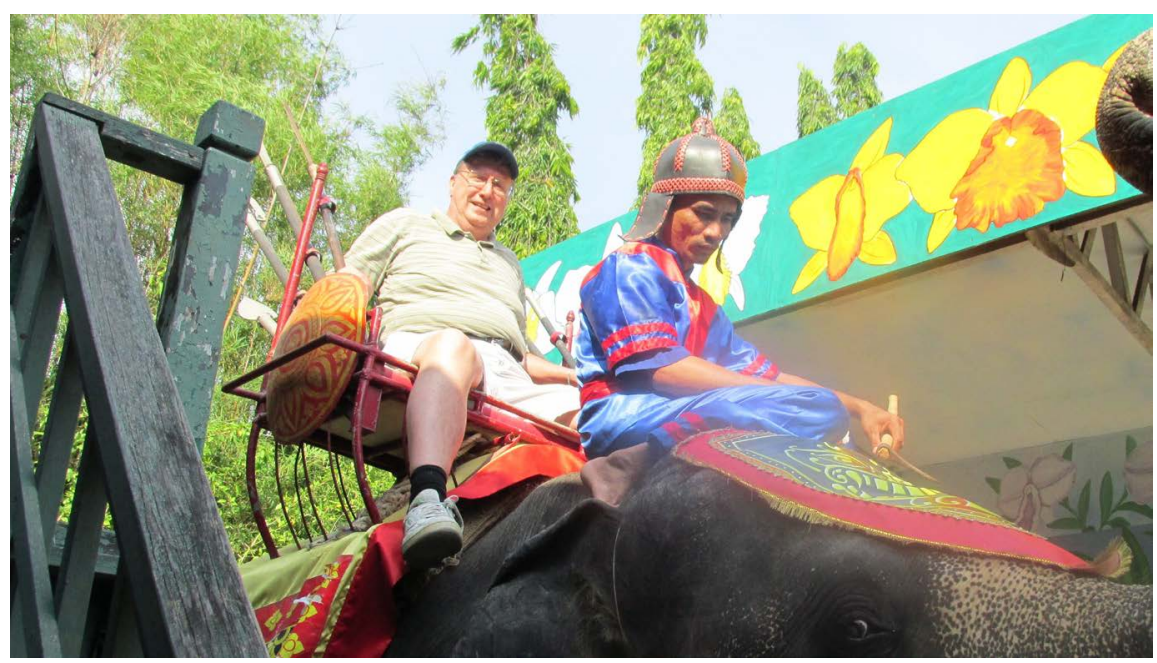

Figure 12. Tourist riding an elephant. Photograph taken by Pam Olson. 


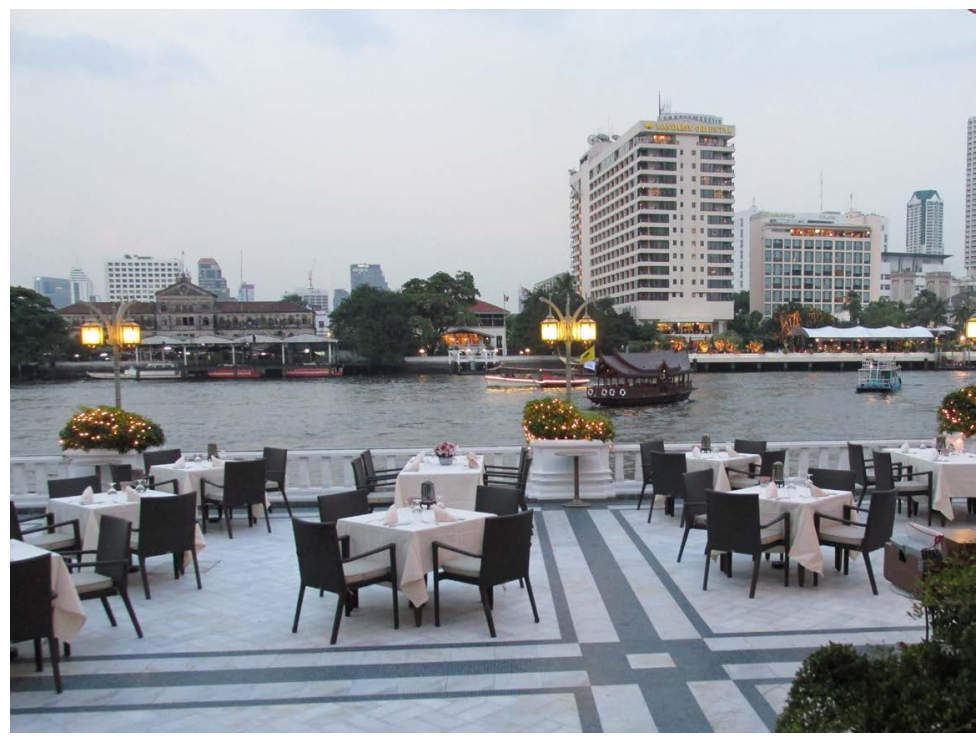

Figure 13. Dining at Oriental hotel along the river. Photograph taken by Pam Olson.

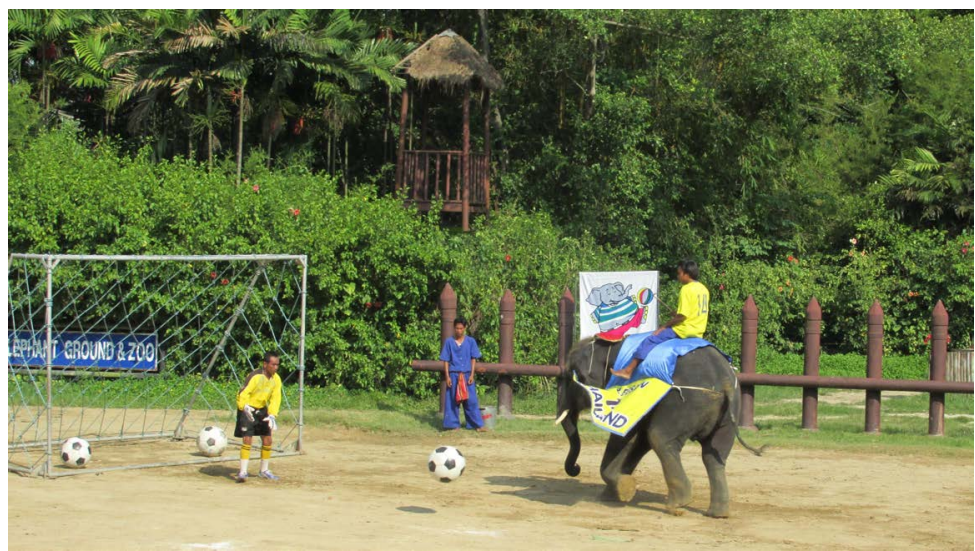

Figure 14. Elephant playing soccer. Photograph taken by Pam Olson.

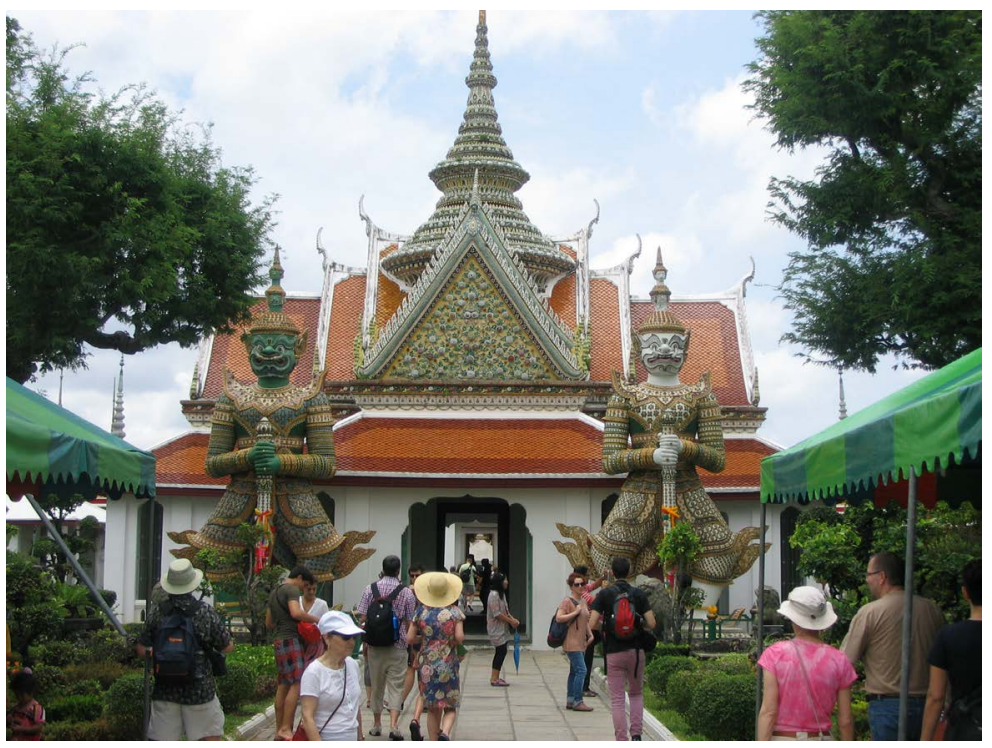

Figure 15. Guarded temple with tourists. Photograph taken by Pam Olson. 


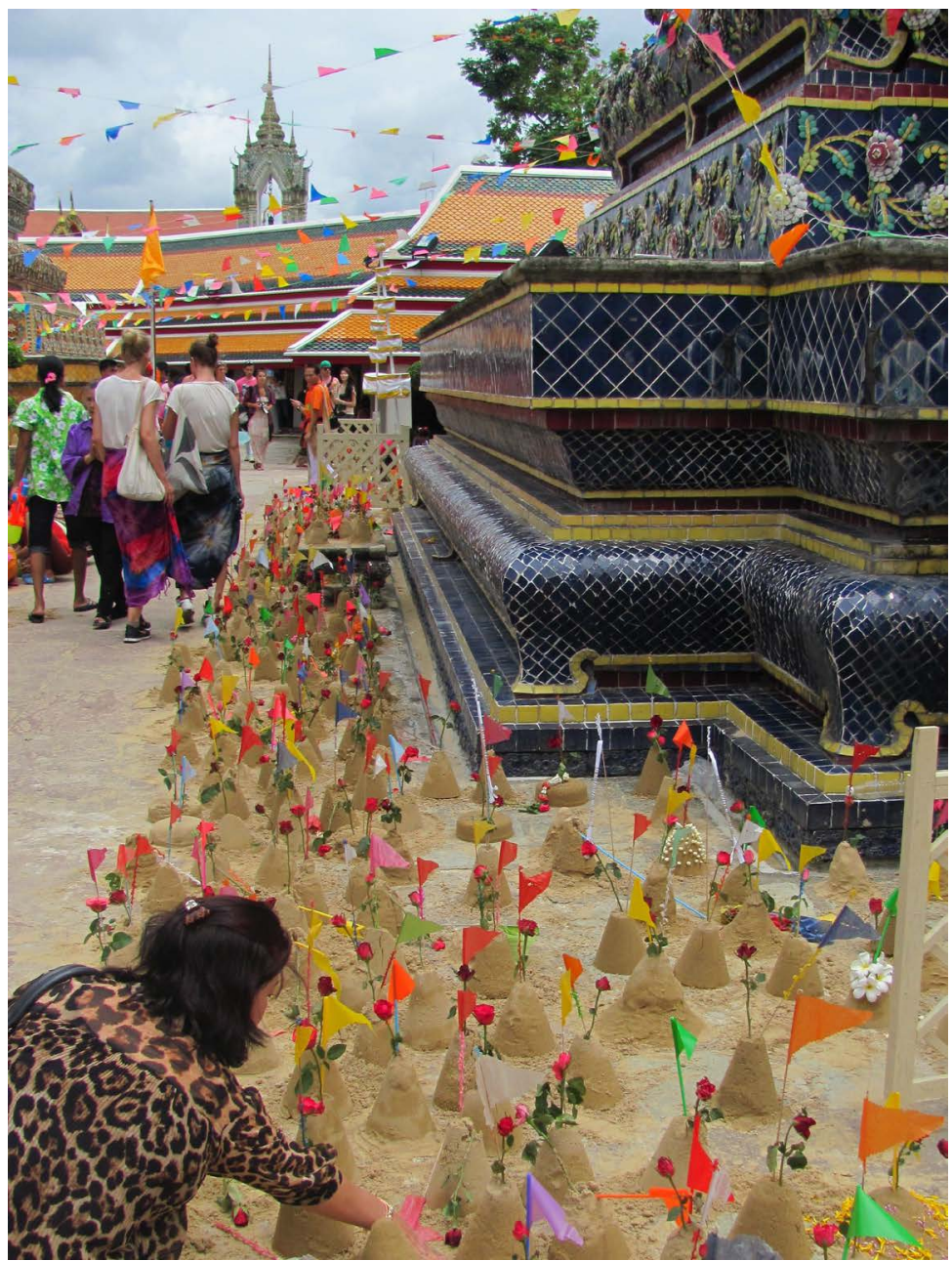

Figure 16. Temples with sand castles in honor of former family members. Photograph taken by Pam Olson.

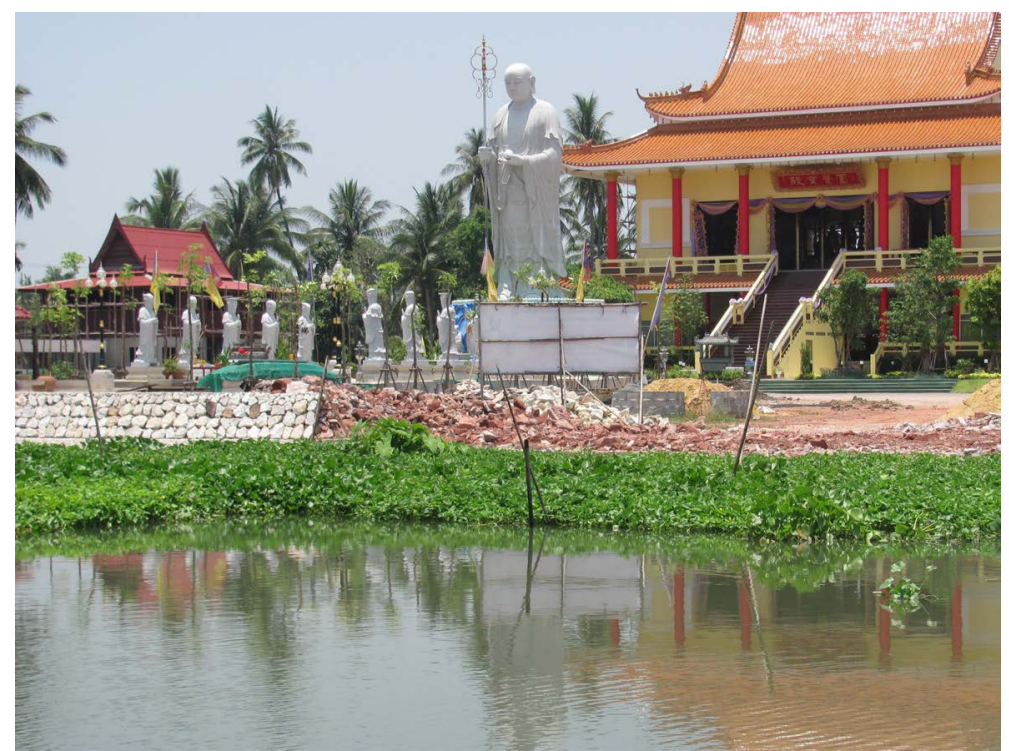

Figure 17. Floodwall repair in front of a Buddist temple. Photograph taken by Pam Olson. 


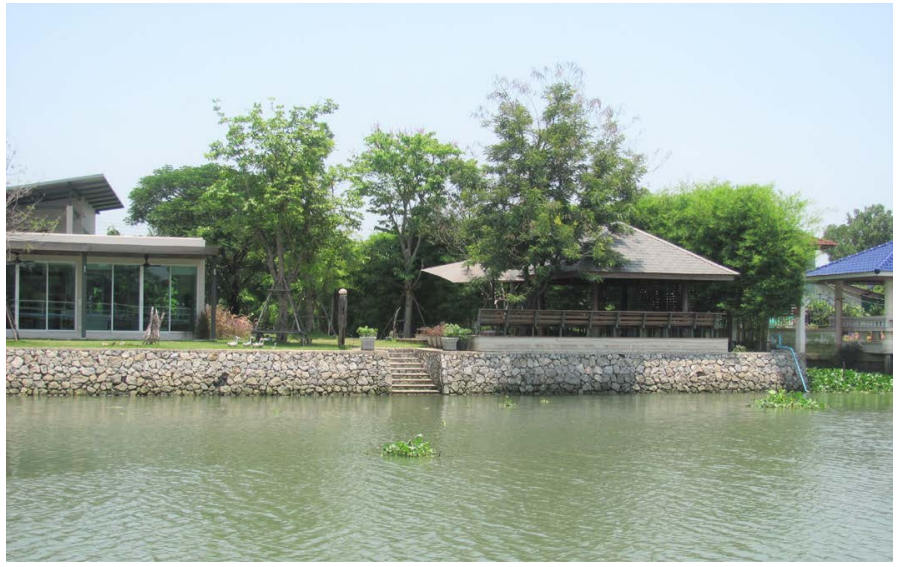

Figure 18. Low floodwall in residential area. Photograph taken by Pam Olson.

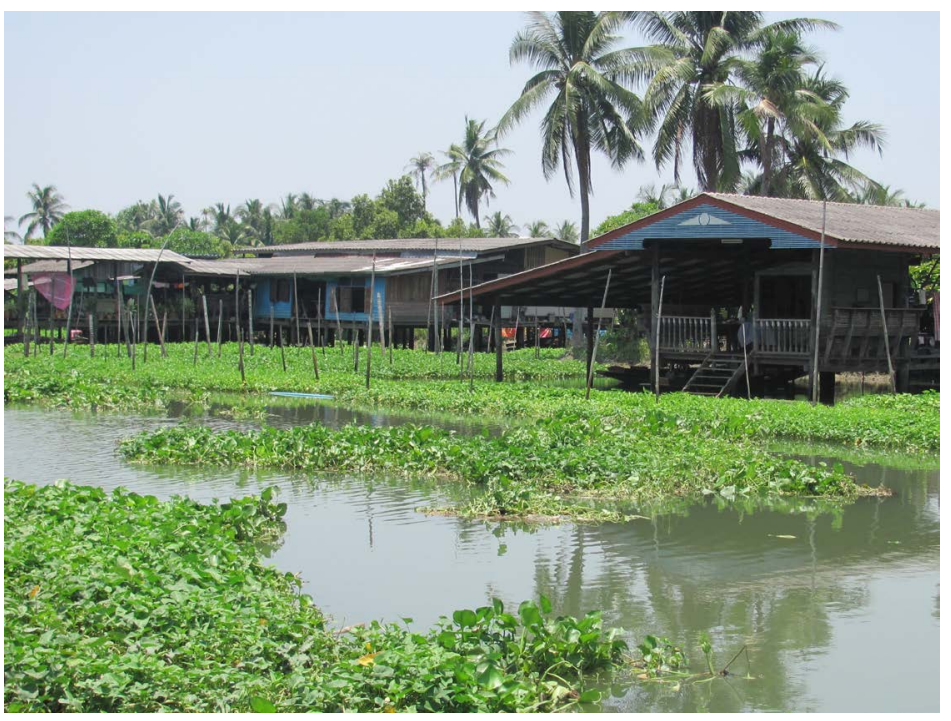

Figure 19. Wetlands and flooding under homes on stilts. Photograph taken by Pam Olson.

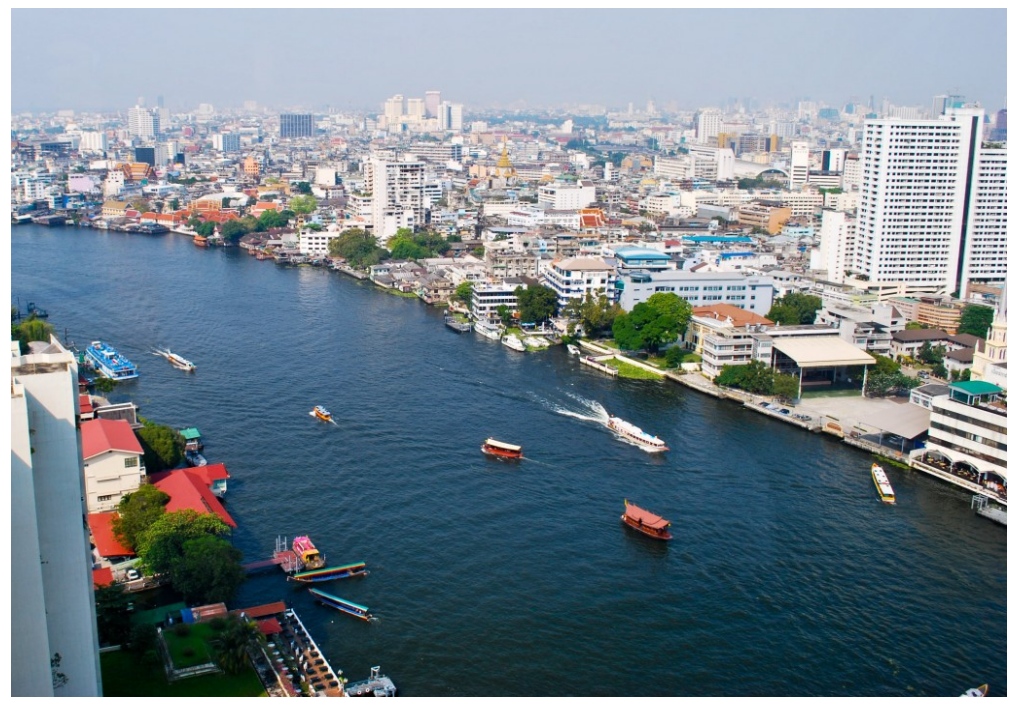

Figure 20. View of blue Chao Phraya River and shoreline can be seen by tourists. 


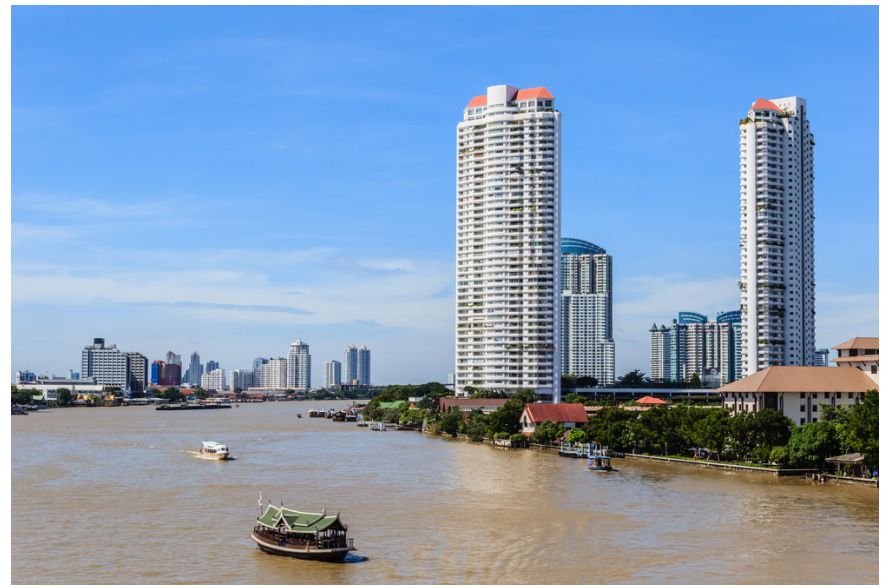

Figure 21. Large skyscrapers along the muddy Chao Phraya River.

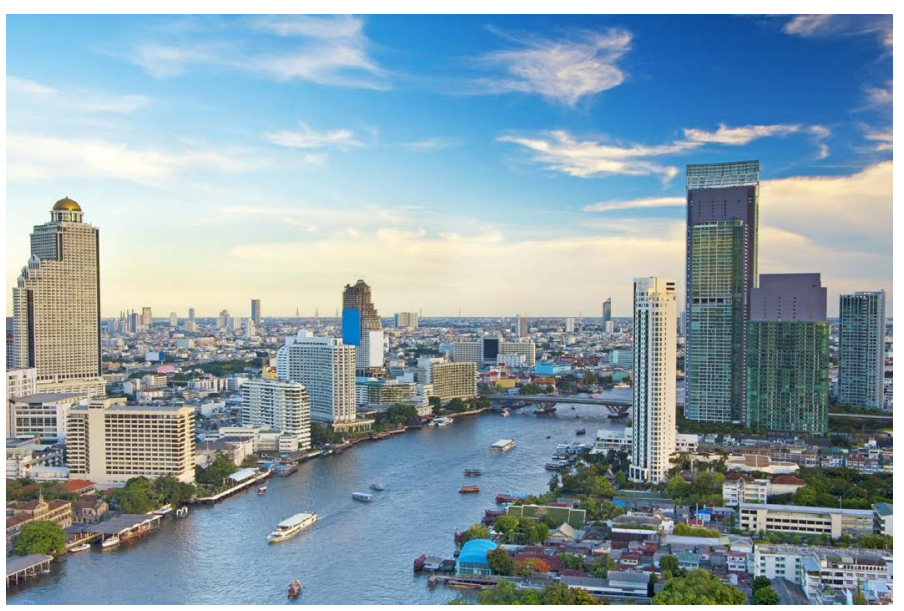

Figure 22. Bangkok and the Chao Phraya River with skyscrapers on both sides of river.

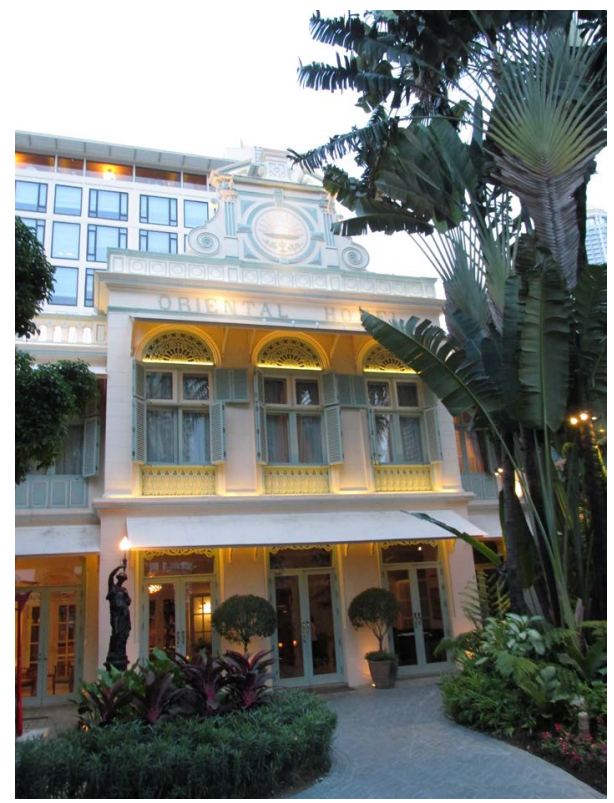

Figure 23. Oriental Hotel which attracts international tourists. Photograph taken by Pam Olson. 
Thep Bridge, trade-in charcoal and others work in rice houses. The loggers and teak traders market their goods around Krung Thon Bridge before it is milled and exported. South of Klong Doei the Chao Phraya River increases in width and banks are covered with greenery (Figure 24). The River banks between Bangkok and Pak Nam are used for commerce. Pak Nam, where many trawlers anchor, has important fish factories, a renowned wat and some good fish restaurants. Klong Doei (Klong Toey) is Bangkok's international port (Figure 25 and Figure 26) where freighters load exports from Thailand. Pak Nam "River Mouth" of the Chao Phraya River is where it flows into the Gulf of Thailand. The $40 \mathrm{~km}$ river channel south of Bangkok is lined with harbor installations (Figure 26). The mouth of the channel requires frequent dredging and vessels are limited to 10,000 tons.

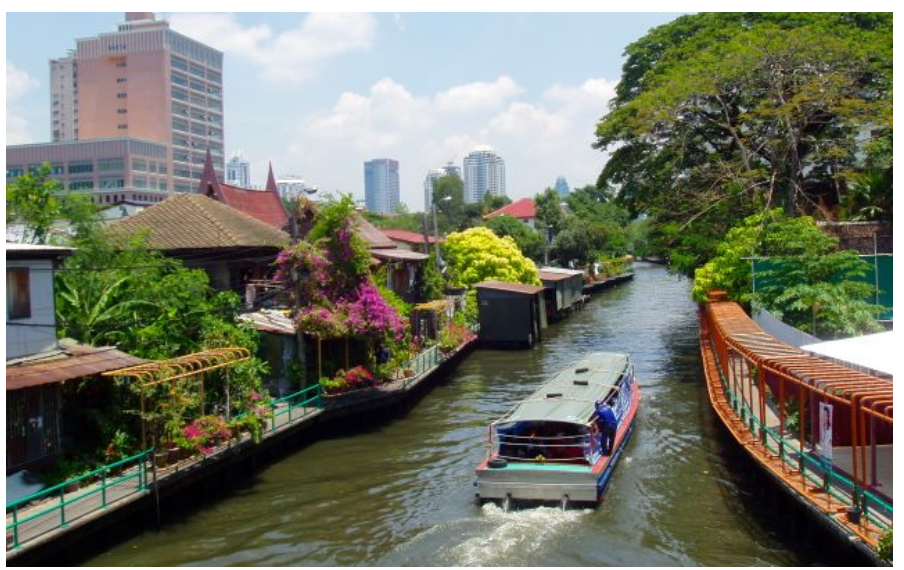

Figure 24. Boat traffic on the canals linked to the Chao Phraya River. Photograph taken by Pam Olson.

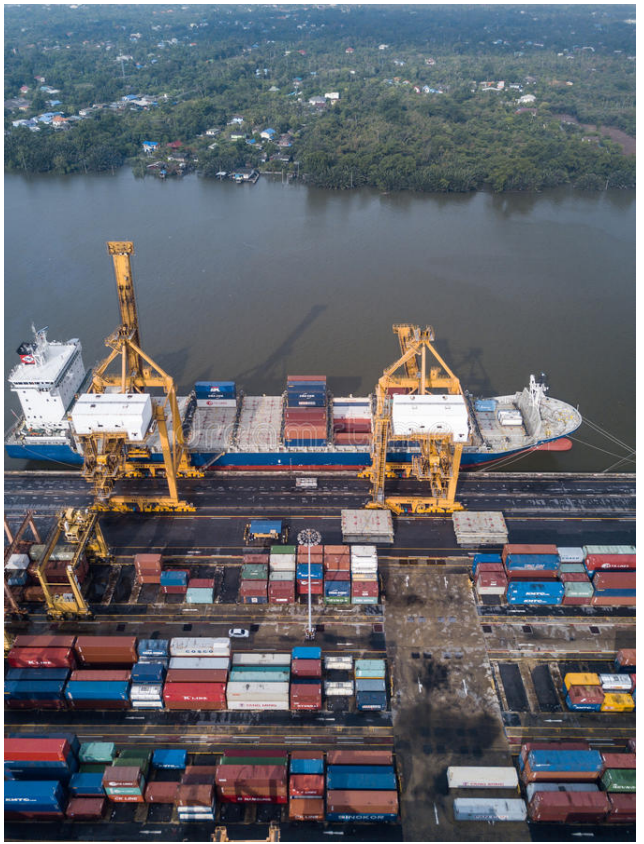

Figure 25. Port of Bangkok with a ship being loaded. 


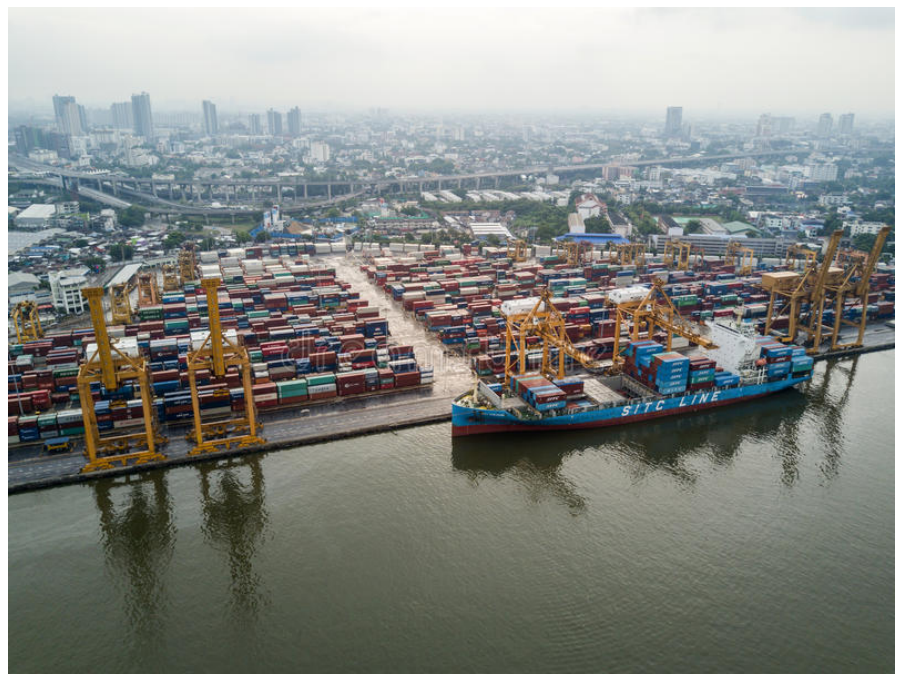

Figure 26. Loaded ship at the Port of Bangkok with City of Bangkok in background.

Land subsidence in Bangkok, Thailand is primarily caused by well pumping and has affected Bangkok for the past 50 years. The impact of the pumping is critical due to the flat low-lying topography and presence of a thick soft lacustrine clay layer which creates foundational engineering problems. Pumping has lowered the water table by as much as $65 \mathrm{~m}$. In the 1980s the subsidence rate subsidence at a rate as high as $12 \mathrm{~cm} / \mathrm{yr}$. Bangkok is sinking and could be underwater in 15 years and there is concern that any action taken will be too late.

In 2011, 800 people were killed by flooding and 12 million others were adversely affected. Bangkok was underwater for months and the economy suffered a US \$41 billion loss. Bangkok is facing multiple challenges. The mean sea level is predicted to rise $1 \mathrm{~m}$ according to the Intergovernmental Panel on Climate Change.

As waters rise the city is sinking and accelerating the process of disappearing living space. Currently Bangkok is 0.5 to $2.0 \mathrm{~m}$ above the water. The metropolitan area is sitting on marshland and resting on a layer of soft highly compressible clay. In addition to natural land subsidence, 5 decades of excessive groundwater pumping and rapid urban development have put pressure on the alluvial and lacustrine foundation. The 5000 tall building (Figure 3 and Figure 4), 9 million vehicles, roads and rail systems have contributed to the pressure.

Subsidence of Bangkok clay due to deep well pumping can be reduced or controlled through artificial recharge [5]. Metropolis, a flood-resistant community could provide the blueprint on how to keep the city above water. Low lyingcommunities could be elevated $5 \mathrm{~m}$ above water to reduce the problems of flooding, rising sea levels and land subsidence. Restored mangrove forests could filter water, absorb carbon dioxide, and provide residents with an elevated community without fear of being flooded or being submerged and green open space.

Experts suggest that unchecked urbanization and eroding shorelines will leave Bangkok residents in a critical situation. With the weight of people and infrastructure contributing to the cities gradual descent into the water, Bangkok has become a casualty of its own successful development. Making the situation 
worse is the canals that are used to traverse the city have been replaced by a network of roads and bridges. The canals (Figure 27 and Figure 28) had contributed to a natural drainage system of waterway pathways. Shrimp farms (Figure 29) and other aqua-cultural development have replaced the shore stabilizing mangrove forests.

\subsection{Ecology and Pollution}

The lowland areas of the Chao Phraya basin in central Thailand are freshwater swamp forest, a subtropical and tropical moist broadleaf forest. The area is $400 \mathrm{~km}$ north to south and $180 \mathrm{~km}$ wide and is in the Chao Phraya River basin (Figure 6). The original swamp forest was converted to rice paddies, other agriculture and urban areas such as Bangkok. Most of the original wildlife is gone, including the birds and fish [8]. Without urban development the area would probably consist of freshwater swamps inland and salty mangroves on the coast and river

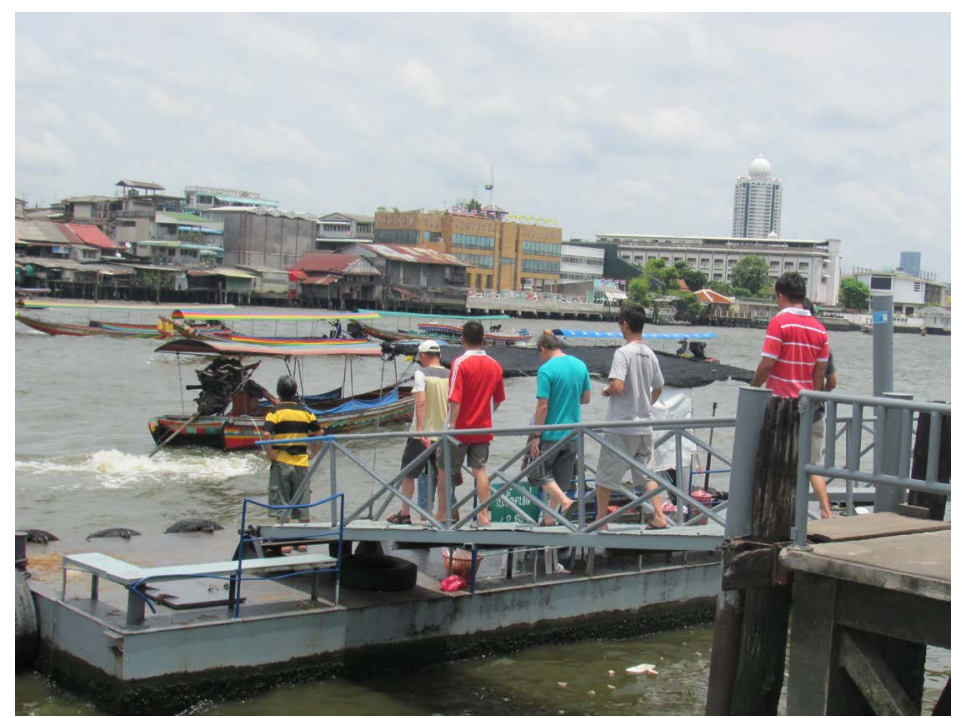

Figure 27. Tourist boats on the Chao Phraya River. Photograph taken by Pam Olson.

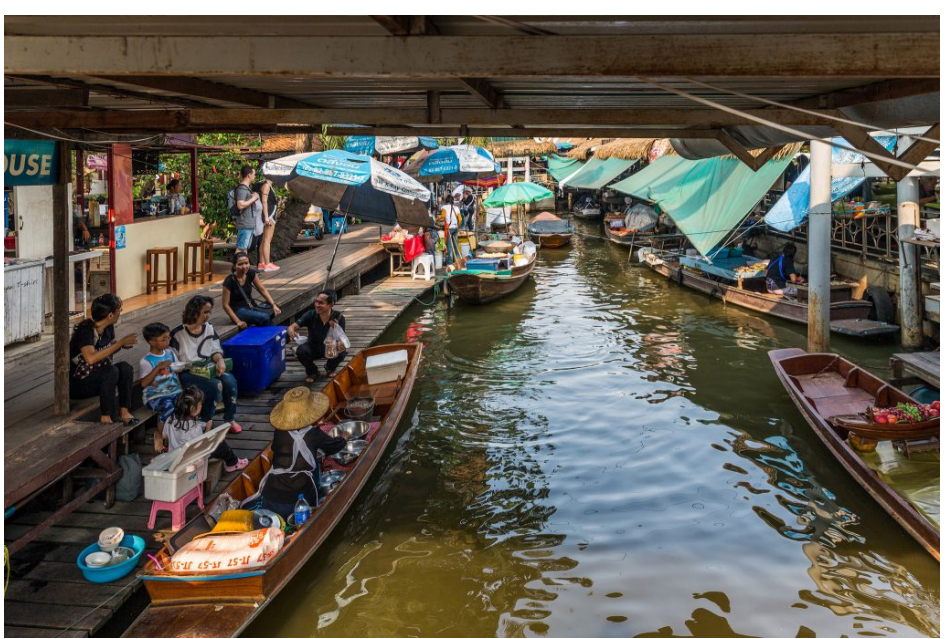

Figure 28. Floating markets on canals. Photograph taken by Pam Olson. 
estuaries. The primary remaining relic of that original landscape is Khao Sam Roi Yot National Park. The Chao Phraya basin has 280 species of fish. The main stem of the Chao Phraya River alone has 190 native fish species. Extensive habitat destruction (pollution, dams, irrigation and drainage) has occurred. Overfishing has also been a historic problem. In the past decade, the Thai Pollution Control Department (PCD) has reported that the Chao Phraya River and tributary water quality have deteriorated. The river system contains bacteria and nutrients (phosphates, phosphorus and nitrogen) pollution. Nutrient pollution accelerates algae growth which harms water quality, marine habitats and food resources for aquatic animals [8]. It also decreases oxygen needed for fish survival. The PCD findings rate water quality very poor and large amounts of wastewater were discharged into the rivers from agriculture, industry (Figure 30) and households.

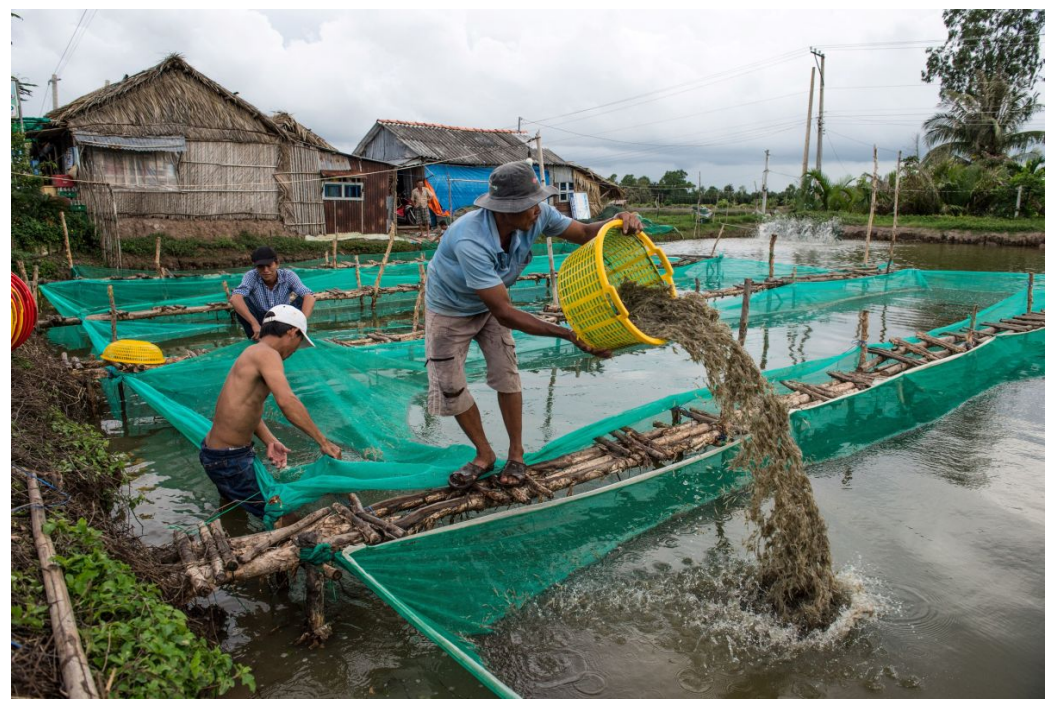

Figure 29. Shrimp farming in Chao Phraya Delta.

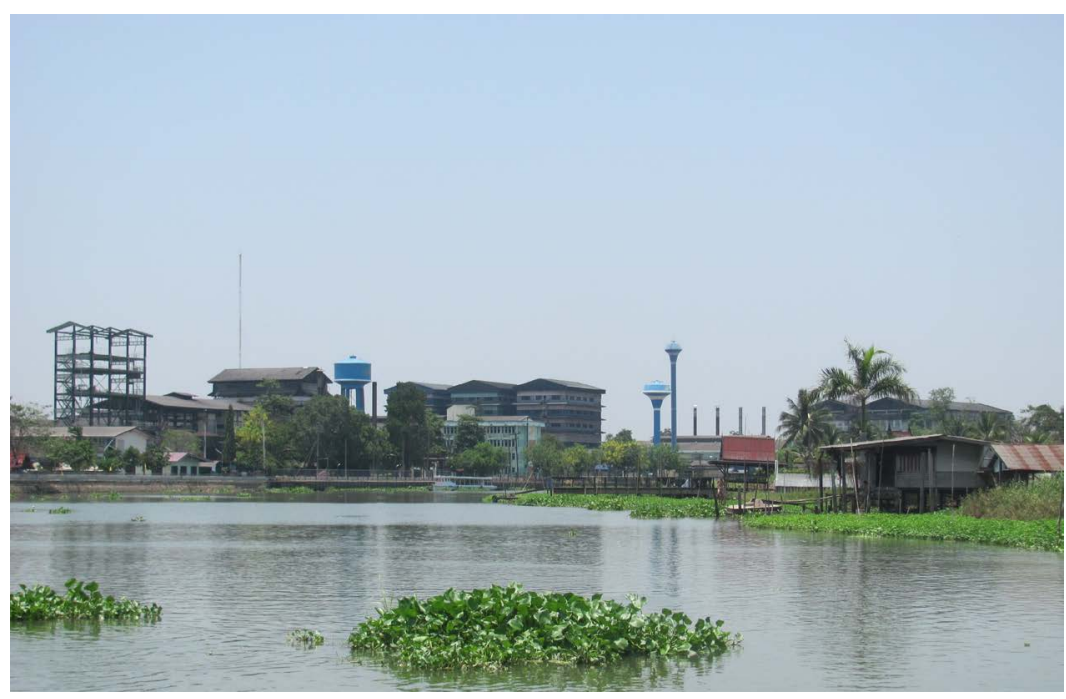

Figure 30. Industry along the Chao Phraya River. Photograph taken by Pam Olson. 


\section{Summary and Conclusions}

The wetlands and land masses are subsiding as a result of the sediment deposition reduction, groundwater extraction, saltwater intrusion, consolidations, reduced sediment loads in the lower Chao Phraya River and reduction in the current plumes into the Gulf of Thailand which takes the fresh water and sediment out into the sea. More intense storms could occur in this region in the future. Bangkok could be trapped by flooding from the seas to the south and monsoonal flooding from the north. The cities weakness is a result of small tunnels and hyper-development of neighborhoods. These small tunnels used to act as water storage basins. The government is scrambling to mitigate the effects of potential climate change, constructing a municipal canal network up to $2600 \mathrm{~km}$ with pumping stations and eight underground tunnels to evacuate water if disaster strikes. In 2017 Chulalongkorn University built a 4 ha park that was designed to drain several million liters of rainwater and redirects it so surrounding neighborhoods are not flooded. These fixes may not be enough.

\section{Acknowledgements}

It is published with funding support from USDA, NIFA, Water Division and Department of Natural Resources and Environmental Sciences and with the approval of the Director of the Illinois Office of Research, College of Agricultural, Consumer, and Environmental Science, University of Illinois, Urbana, Illinois.

\section{Conflicts of Interest}

The authors declare no conflicts of interest regarding the publication of this paper.

\section{References}

[1] Warren, W. and Lloyd, R.I. (2012) Bangkok Waterways. Asia Books, Bangkok, Thailand.

[2] Olson, K.R. and Morton, L.W. (2018) Tonle Sap Lake and River and Confluence with the Mekong River in Cambodia. Journal of Soil and Water Conservation, 73 , 60A-66A. https://doi.org/10.2489/jswc.73.3.60A

[3] Olson, K.R. and Morton, L.W. (2018) Polders, Dikes, Canals, Rice and Aquaculture in the Mekong Delta. Journal of Soil and Water Conservation, 73, 83A-89A. https://doi.org/10.2489/jswc.73.4.83A

[4] Achalabhuti, C. (1974) Petroleum Geology of the Gulf of Thailand. Conf. Circum-Pacific Energy and Mineral Resources. Honolulu, Hawaii.

[5] Muktabhant, C., Teerawong, P. and Tengamanuary, V. (1966) Engineering Properties of Bangkok Subsoils. Chulaongkorn University, Bangkok.

[6] Piyasen, W. (1982) Rehabilitation of Depleted Aquifer System through Artificial Recharge-An Application to Bangkok. Doctoral Dissertation, No. GT-82-1, Asian Institute of Technology, Bangkok, Thailand.

[7] Nutalaya, P., Young, R.N. Chumnankat, T. and Buapeng, S. (1996) Land Subsi- 
dence in Bangkok during 1978-1988. In: Millim, J.D. and Hag, B.U., Eds., Sea-Level Rise and Coastal Subsidence, Springer, Dordrecht, 105-130. https://doi.org/10.1007/978-94-015-8719-8_6

[8] Samorn, M.S. and Sales, C.L. (1994) Water Quality Management of the Chao Phraya River. FishBase: Fish Species of the Chao Phraya River. Environmental Technology, 15, 501-516. 